\title{
PEMBIAYAAN MURABAHAH PADA PERBANKAN SYARIAH DI INDONESIA
}

\author{
Surayya Fadhilah Nasution \\ Universitas Islam Negeri Sumatera Utara \\ surayyafadhilah130496@gmail.com
}

\begin{abstract}
The research purpose to find out how ismurabahah financing in Indonesia Islamic banking. The research method is used in the form of library research which collecting data by using written materials. Islamic banking has two intermediation functions. First, Islamic banking raise funds from the people and second, Islamic banking distribute funds via financing. One of Islamic banking financing is murabahah. Murabahah is selling/purchasing transaction with the agreed profit. Murabahah characteristic is the seller has to tell to the buyer about product purchase price and agreed profit. Murabahah has two ways, murabahah with order and without order. The survey results shown that Islamic banking has applied murabahah as their main financing.
\end{abstract}

Keywords: Islamic banking, financing, murabahah.

\begin{abstract}
Abstrak
Tujuan penelitian ini untuk mengetahui bagaimana pembiayaan murabahah pada perbankan syariah di Indonesia. Metode penelitian yang digunakan adalah penelitian pustaka atau library research yaitu menghimpun data dengan cara menggunakan bahan-bahan tertulis.Bank syariah sebagai lembaga keuangan syariah memiliki fungsi intermediasi, yaitu bank syariah melakukan penghimpunan dana dari masyarakat dalam bentuk simpanan dan menyalurkannya melalui skema pembiayaan. Salah satu bentuk penyaluran dana pada bank syariah ialah melalui produk pembiayaan murabahah. Murabahah adalah jual beli barang pada harga asal dengan tambahan keuntungan yang sudah disepakati. Karakteristik murabahah yaitu bahwa penjual harus memberi tahu pembeli mengenai harga pembelian produk dengan menyatakan jumlah keuntungan yang ditambahkan pada biaya tersebut. ${ }^{6}$ Murabahah dapat dilakukan dengan dua cara, yaitu pembelian dengan pesanan dan tanpa pesanan. Beberapa hasil survey menunjukkan bahwa bank-bank syariah baik yang terdapat di Indonesia ataupun di luar negeri banyak yang menerapkan murabahah sebagai metode pembiayaan mereka yang utama.

Kata kunci: Perbankan syariah, pembiayaan, murabahah.
\end{abstract}

\section{Pendahuluan}

Saat ini, ekonomi syariah mengalami pertumbuhan yang cukup pesat. Studi dan konsep ekonomi syariah tidak hanya dilakukan di negara-negara yang mayoritas 
penduduknya Muslim, namun negara-negara non Muslim, seperti Amerika Serikat dan negara-negara Eropa banyak mengkaji mengenai konsep ekonomi syariah. Terlebih setelah terjadi serangkaian krisis yang menimpa negara-negara kapitalisme yang tiada hentinya, sehingga ada pemikiran bahwa diperlukan sistem ekonomi baru sebagai pengganti sistem ekonomi liberal dan kapitalisme yang dianggap gagal. Salah satu turunan dari ekonomi syariah adalah perbankan syariah. ${ }^{1}$

Saat ini, perbankan syariah mengalami pertumbuhan yang cukup pesat terutama di Indonesia, seiring dengan tumbuhnya pemahaman masyarakat bahwa bunga dan modal yang ditentukan di awal (predetermined return) merupakan riba yang dilarang oleh syariat Islam. Berdasarkan pemahaman tersebut, maka sejak tahun 1950 banyak cendikiawan Muslim dan teoritis ekonomi Islam menghendaki perbankan yang terbebas dari bunga atau riba. ${ }^{2}$

Akan tetapi, walaupun bank syariah mengalami perkembangan yang begitu cepat dan pesat, sebagian masyarakat masih ada yang berasumsi bahwa bank syariah hanyalah sebuah label yang digunakan untuk menarik simpati masyarakat Muslim di bidang perbankan. Mereka berpendapat bahwa bank syariah merupakan bank konvensional yang menggunakan istilah-istilah Islam dengan kepala akad yang dibubuhi kalimat Bismillahirrahmanirrahim serta pegawai yang mengenakan busana Islami dan mengucapkan salam, akan tetapi dalam pelaksanaan akadnya masih menggunakan cara-cara yang dilarang oleh agama. Sikap skeptis dari masyarakat tentang perbankan syariah tersebut tidak dapat dipungkiri karena konotasi perbankan sejak dahulu memang terpisah secara nyata dengan syariah, sehingga pada awal mula pembentukan perbankan syariah banyak yang tidak percaya akan adanya keberhasilan ekonom Islam dalam menyatukan institusi perbankan dengan syariah. ${ }^{3}$

Bank syariah merupakan bank yang menggunakan prinsip syariah dalam menjalankan kegiatan usahanya, dimana landasan hukumnya mengacu kepada alqur'an dan hadits. ${ }^{4}$ Bank syariah sebagai lembaga keuangan syariah memiliki fungsi intermediasi, yaitu bank syariah melakukan penghimpunan dana dari masyarakat dalam bentuk simpanan dan menyalurkannya melalui skema pembiayaan. Salah satu bentuk penyaluran dana pada bank syariah ialah melalui produk pembiayaan murabahah. ${ }^{5}$ 
Murabahah adalah jual beli barang pada harga asal dengan tambahan keuntungan yang sudah disepakati. Karakteristik murabahah yaitu bahwa penjual harus memberi tahu pembeli mengenai harga pembelian produk dengan menyatakan jumlah keuntungan yang ditambahkan pada biaya tersebut. ${ }^{6}$ Murabahah dapat dilakukan dengan dua cara, yaitu pembelian dengan pesanan dan tanpa pesanan. Beberapa hasil survey menunjukkan bahwa bank-bank syariah baik yang terdapat di Indonesia ataupun di luar negeri banyak yang menerapkan murabahah sebagai metode pembiayaan mereka yang utama. ${ }^{7}$ Perbankan syariah lebih tertarik dengan sistem murabahah karena keuntungan bersifat pasti dan tidak rumit dalam praktiknya, sehingga murabahah mendominasi 60\%-90\% dalam skema pembiayaan perbankan syariah. Hal inilah yang memicu sejumlah kritikan karena praktik murabahah tak ubahnya dengan bunga dalam perbankan konvensional yang keuntungannya bersifat pasti, yang berbeda hanya basis akadnya saja, yaitu murabahah berdasarkan jual beli, sementara bunga berbasis hutang. Namun, yang menjadi masalah adalah bukan besarnya saluran pembiayaan pada akad murabahah di perbankan syariah karena murabahah diakui secara syah oleh syariah, tetapi masalah timbul karena adanya penyimpangan dalam praktik akad murabahah, sehingga apakah penyimpangan-penyimpangan tersebut legal secara syariah atau tidak. ${ }^{8}$

Dari permasalahan diatas, penulis akan mencoba membahas terkait mengenai pembiayaan murabahah pada perbankan syariah khususnya di Indonesia, dimana tujuan penelitian ini untuk mengetahui bagaimana pembiayaan murabahah pada perbankan syariah di Indonesia.

\section{Kajian Teori}

\section{Defenisi Murabahah}

Secara bahasa murabahah berasal dari kata ar-ribh yang berarti keuntungan dalam perniagaan. Menurut istilah fuqaha' murabahah adalah menjual barang dengan harga awal (harga beli) dengan tambahan keuntungan yang diketahui. ${ }^{9}$ Al-Marghinani mendefenisikan murabahah sebagai penjualan barang apa pun pada harga pembelian yang ditambah dengan jumlah yang tetap sebagai keuntungan, sedangkan Ibnu Qudamah beserta fuqaha Hambali berpendapat bahwa murabahah adalah penjualan 
pada biaya modal ditambah dengan keuntungan yang diketahui, pengetahuan atas biaya modal merupakan persyaratan atasnya. Oleh karena itu, penjual akan mengatakan "Biaya modal saya yang terkait dalam transaksi ini adalah sekian atau pembelian barang saya sebesar 100 dan saya menjualnya ke anda pada biaya ini ditambah keuntungan sebesar 10". Hal ini sah secara hukum tanpa ada kontroversi sedikitpun dari para fuqaha. ${ }^{10}$

Pada dasarnya, jumhur ulama sepakat bahwa murabahah merupakan salah satu bentuk jual beli yang dibolehkan karena keumuman ayat "Allah menghalalkan jual beli dan mengharamkan riba". Namun, terjadi perbedaan pendapat pada mazhab Hambali terhadap hukum murabahah. Ulama Hanabilah berpendapat bahwa terdapat dua bentuk murabahah. Pertama, jika keuntungan diketahui dari bentuk utuh modal, misalnya penjual berkata "Dari modal 100 dirham saya tambah keuntungan 10 dirham", maka hal ini dibolehkan tanpa ada ikhtilaf diantara ulama Hanabilah. Kedua, jika keuntungan dihitung dari tiap bagian modal, misalnya penjual berkata "Dari modal 100 dirham, maka aku ambil keuntungan sebesar 1 dirham dari tiap 10 dirhamnya", dalam hal ini ulama Hanabilah kebanyakan membencinya. ${ }^{11}$

Beda halnya dengan Ibnu Hazm yang mengatakan bahwa murabahah merupakan bentuk jual beli yang bathil karena menurutnya mensyaratkan adanya penjelasan mengenai keuntungan yang disebutkan tidak terdapat dalam nash, sementara yang ada nash-nya adalah jual beli tanpa adanya syarat penyebutan keuntungan. Tetapi, hal ini dibolehkan (murabahah) jika pada suatu negeri tidak terjadi jual beli, kecuali dengan cara penyebutan modal dan tambahan keuntungan secara jelas. ${ }^{12}$

Berdasarkan uraian di atas, maka dapat diartikan murabahah dalam perbankan syariah adalah jual beli barang pada harga asal dengan tambahan keuntungan yang disepakati antara pihak bank dan nasabah. Dalam murabahah penjual menyebutkan harga pembelian barang kepada pembeli, kemudian ia mensyaratkan atas laba dalam jumlah tertentu. Dalam daftar istilah buku himpunan fatwa DSN (Dewan Syariah Nasional) dijelaskan bahwa yang dimaksud murabahah adalah menjual suatu barang dengan menegaskan harga belinya kepada pembeli dan pembeli membelinya dengan harga yang lebih sebagai laba. ${ }^{13}$ 


\section{Landasan Hukum Murabahah}

\section{Al-Qur'an}

"Hai orang-orang yang beriman, janganlah kamu saling memakan harta sesamamu dengan jalan yang batil, kecuali dengan jalan perniagaan yang berlaku dengan suka sama-suka di antara kamu dan janganlah kamu membunuh dirimu[287]. Sesungguhnya Allah adalah Maha Penyayang kepadamu” (Q.S. An-Nisaa’: 29).

“Orang-orang yang Makan (mengambil) riba[174] tidak dapat berdiri melainkan seperti berdirinya orang yang kemasukan syaitan lantaran (tekanan) penyakit gila[175]. Keadaan mereka yang demikian itu, adalah disebabkan mereka berkata (berpendapat), sesungguhnya jual beli itu sama dengan riba, padahal Allah telah menghalalkan jual beli dan mengharamkan riba. orang-orang yang telah sampai kepadanya larangan dari Tuhannya, lalu terus berhenti (dari mengambil riba), maka baginya apa yang telah diambilnya dahulu[176] (sebelum datang larangan) dan urusannya (terserah) kepada Allah. Orang yang kembali (mengambil riba), maka orang itu adalah penghunipenghuni neraka, mereka kekal di dalamnya” (Q.S. Al-Baqarah: 275). ${ }^{14}$

2. Hadits

"Dari Suhaib ar Rumi r.a. bahwa Rasulullah saw. bersabda 'Tiga hal yang didalamnya terdapat keberkahan: jual beli secara tangguh, muqaradah (mudharabah), dan mencampur gandum dengan tepung untuk keperluan rumah, bukan untuk dijual"' (H.R. Ibn Majah dari Suhaib).

"Sesungguhnya jual beli itu harus dilakukan suka sama suka" (H.R. Al-Baihaqi dan Ibnu Majah).

\section{Fatwa DSN-MUI}

Fatwa Dewan Syariah Nasional Nomor 04 DSN-MUI/IV/2000 tanggal 1 April 2000 tentang murabahah, yangmana berisi:

1) Ketentuan Umum:

a. Bank dan nasabah harus melakukan akad murabahah yang bebas riba.

b. Barang yang diperjualbelikan tidak diharamkan oleh syariat Islam. 
c. Bank membiayai sebagian atau seluruh harga pembelian barang yang telah disepakati kualifikasinya.

d. Bank membeli barang yang diperlukan oleh nasabah atas nama bank sendiri dan pembelian ini harus sah dan bebas riba.

e. Bank harus menyampaikan semua hal yang berkaitan dengan pembelian, misalnya jika pembelian dilakukan secara hutang.

f. Bank kemudian menjual barang tersebut kepada nasabah (pemesan) dengan harga jual senilai harga beli plus keuntungannya. Dalam kaitan ini bank harus memberitahu secara jujur harga pokok barang kepada nasabah berikut biaya yang diperlukan.

g. Nasabah membayar harga barang yang telah disepakati tersebut pada jangka waktu tertentu yang telah disepakati.

h. Untuk mencegah terjadi penyalahgunaan atau kerusakan akad tersebut, pihak bank dapat mengadakan perjanjian khusus dengan nasabah.

i. Jika bank hendak mewakilkan kepada nasabah untuk membeli barang kepada pihak ketiga, akad jual beli murabahah harus dilakukan setelah barang secara prinsip menjadi milik bank.

2) Ketentuan murabahah kepada nasabah:

a. Nasabah menyampaikan pengajuan dan membuat perjanjian pembelian suatu barang atau aset kepada bank.

b. Jika bank menerima pengajuan tersebut, maka ia harus membeli terlebih dahulu aset yang dipesannya secara sah kepada pedagang.

c. Bank kemudian menawarkan aset tersebut kepada nasabah dan nasabah harus menerima (membelinya) sesuai dengan perjanjian yang telah disepakatinya karena secara hukum perjanjian tersebut mengikat. Kemudian, kedua belah pihak harus membuat kontrak jual beli.

d. Dalam jual beli ini bank dibolehkan meminta nasabah untuk membayar uang muka saat menandatangani kesepakatan awal pemesanan.

e. Jika nasabah kemudian menolak membeli barang tersebut, maka biaya yang telah dikeluarkan harus dibayar dari uang muka yang telah disetorkan. 
f. Jika nilai uang muka kurang dan kerugian harus ditanggung oleh bank, maka bank dapat meminta sisa kerugiannya kepada nasabah.

g. Jika uang muka memakai kontrak 'urbun sebagai alternatif dari uang muka, maka:

- Jika nasabah memutuskan untuk membeli barang tersebut, ia tinggal membayar sisa harga.

- Jika nasabah batal membeli, maka uang muka menjadi milik bank maksimal sebesar kerugian yang ditanggung oleh bank akibat pembatalan tersebut dan jika uang muka tidak mencukupi, maka nasabah wajib melunasi kekurangannya.

3) Jaminan dalam murabahah:

a. Jaminan dalam murabahah dibolehkan agar nasabah serius dengan pesanannya.

b. Bank dapat meminta nasabah untuk menyediakan jaminan yang dapat dipegang.

4) Hutang dalam murabahah:

a. Secara prinsip penyelesaian hutang nasabah dalam transaksi murabahah tidak ada kaitannya dengan transaksi lain yang dilakukan oleh nasabah dengan pihak ketiga atas barang tersebut. Jika nasabah menjual kembali barang tersebut dengan keuntungan atau kerugian, maka ia tetap berkewajiban untuk menyelesaikan hutangnya kepada bank.

b. Jika nasabah menjual barang tersebut sebelum masa angsuran berakhir, maka ia tidak wajib segera melunasi seluruh angsurannya.

c. Jika penjualan barang tersebut menyebabkan kerugian, maka nasabah tetap harus menyelesaikan hutangnya sesuai kesepakatan awal. Ia tidak boleh memperlambat pembayaran angsuran atau meminta kerugian itu diperhitungkan.

5) Penundaan pembayaran dalam murabahah:

a. Nasabah yang memiliki kemampuan tidak dibenarkan menunda penyelesaian hutangnya.

b. Jika nasabah sengaja menunda pembayaran atau salah satu pihak tidak menunaikan kewajibannya, maka dapat diselesaikan melalui Badan Arbitrasi Syariah setelah musyawarah yang dilakukan tidak mencapai kesepakatan. 
6) Bangkrut dalam murabahah:

Jika nasabah telah dinyatakan pailit dan gagal menyelesaikan hutangnya, maka bank harus menunda tagihan hutang sampai ia menjadi sanggup kembali atau berdasarkan kesepakatan. ${ }^{15}$

\section{Rukun Murabahah}

Murabahah merupakan bagian dari jual beli, maka pada dasarnya rukun dan syarat jual beli murabahah juga sama dengan rukun dan syarat jual beli secara umum. Rukun jual beli menurut mazhab Hanafi adalah ijab dan qabul, sedangkan menurut jumhur ulama terdapat empat rukun dalam jual beli, yaitu penjual, pembeli, barang atau sesuatu yang diakadkan, dan sighat. Adapun untuk rukun jual beli murabahah itu sendiri, diantaranya:

1. Penjual (bai')

Penjual adalah pihak bank yang membiayai pembelian barang yang diperlukan oleh nasabah pemohon pembiayaan dengan sistem pembayaran yang ditangguhkan. Biasanya di dalam teknis aplikasinya bank membeli barang yang diperlukan nasabah atas nama bank itu sendiri, walaupun terkadang bank menggunakan media akad wakalah dalam pembelian barang, dimana si nasabah sendiri yang membeli barang yang diinginkan atas nama bank.

\section{Pembeli (musytari')}

Pembeli dalam pembiayaan murabahah adalah nasabah yang mengajukan permohonan pembiayaan ke bank.

\section{Objek jual beli (mabi')}

Biasanya dalam permohonan pembiayaan murabahah sebagian besar nasabah lebih memilih barang-barang yang bersifat konsumtif untuk pemenuhan kebutuhan produksi, seperti rumah, tanah, mobil, motor, dan sebagainya. Namun demikian, terdapat beberapa hal yang harus diperhatikan terkait mengenai syarat-syarat benda atau barang yang menjadi objek akad, antara lain:

a. Suci, maka tidak sah penjualan barang-barang najis, seperti anjing, babi, dan sebagainya yang termasuk dalam kategori najis.

b. Manfaat menurut syara', berdasarkan ketentuan ini, maka tidak boleh jual beli yang tidak diambil manfaatnya menurut syara'. 
140 AT-TAWASSUTH: Jurnal Ekonomi Islam, Volume VI No. 1

Januari - Juni 2021: 132 - 152

c. Jangan ditaklikan, maksudnya apabila dikaitkan atau digantungkan kepada halhal lain, seperti “Jika Bapakku pergi, ku jual kendaraan ini kepadamu”.

d. Tidak dibatasi waktu, dalam hal perkataan "Saya jual kendaraan ini kepada tuan selama satu tahun”, maka penjualan tersebut tidak sah, sebab jual beli merupakan salah satu penyebab pemilikan sacara penuh yang tidak dibatasi ketentuan syara'.

e. Dapat dipindah tangankan atau diserahkan, karena memang dalam jual beli barang yang menjadi objek akad harus beralih kepemilikannya dari penjual ke pembeli. Cepat atau lambatnya penyerahan, hal itu tergantung pada jarak atau tempat diserahkannya barang tersebut.

f. Milik sendiri, tidak dihalalkan menjual barang-barang milik orang lain tanpa seizin dari pemilik barang tersebut. Sama halnya dengan barang-barang yang baru akan menjadi miliknya.

g. Diketahui (dilihat), barang yang menjadi obyek jual beli harus diketahui spesifikasinya, seperti kuantitasnya, ukurannya, modelnya, warnanya, dan halhal lain yang terkait. Maka tidak sah jual beli yang menimbulkan keraguan salah satu pihak.

\section{Harga (tsaman)}

Harga dalam pembiayaan murabahah dianalogikan dengan pricing atau plafond pembiayaan.

\section{Ijab qabul}

Dalam perbankan syariah dimana segala operasionalnya mengacu kepada hukum Islam, maka akad yang dilakukan juga memiliki konsekuensi duniawi dan ukhrawi. Dalam akad biasanya memuat tentang spesifikasi barang yang diinginkan nasabah, kesediaan pihak bank syariah dalam pengadaan barang, juga pihak bank syariah harus memberitahukan harga pokok pembelian dan jumlah keuntungan yang ditawarkan kepada nasabah (terjadi penawaran), kemudian penentuan lama angsuran apabila terdapat kesepakatan murabahah. ${ }^{16}$ 


\section{Syarat Murabahah}

Selain rukun dalam pembiayaan murabahah, juga terdapat syarat-syarat yang menjadi pedoman dalam pembiayaan sekaligus sebagai identitas suatu produk dalam bank syariah, syarat-syarat tersebut antara lain:

1. Penjual memberitahukan harga pokok kepada calon pembeli. Hal ini logis karena harga yang akan dibayar pembeli kedua (nasabah) didasarkan pada modal si pembeli awal (bank).

2. Akad pertama harus sah sesuai dengan rukun yang ditetapkan.

3. Akad harus bebas dari riba.

4. Penjual harus menjelaskan kepada pembeli bila terjadi cacat atas barang sesudah pembelian.

5. Penjual harus menyampaikan semua hal yang berkaitan dengan pembelian, misalnya pembelian dilakukan secara hutang. ${ }^{17}$

\section{Jenis-Jenis Murabahah}

1. Murabahah tanpa pesanan

Murabahah tanpa pesanan adalah jenis jual beli murabahah yang dilakukan dengan tidak melihat adanya nasabah yang memesan atau mengajukan pembiayaan atau tidak, sehingga penyediaan barang yang dilakukan oleh bank syariah tidak terkait dengan jual beli murabahah itu sendiri. Dengan kata lain, dalam murabahah ini, bank syariah menyediakan barang yang akan diperjualbelikan tersebut tanpa memperhatikan ada nasabah yang membeli atau tidak. Dalam hal ini, proses pengadaan barang dilakukan sebelum transaksi/akad jual beli murabahah dilakukan. Pengadaan barang yang dilakukan bank syariah dapat dilakukan dengan beberapa cara, antara lain:

a. Membeli barang jadi kepada produsen (prinsip murabahah).

b. Memesan kepada produsen dengan pembayaran dilakukan secara keseluruhan setelah akad (prinsip salam).

c. Memesan kepada produsen dengan pembayaran yang dilakukan di depan selama dalam masa pembuatan atau setelah penyerahan barang (prinsip istishna').

d. Merupakan barang-barang dari persediaan mudharabah atau musyarakah. 
Alur transaksi murabahah tanpa pesanan dapat dilihat dalam skema berikut:

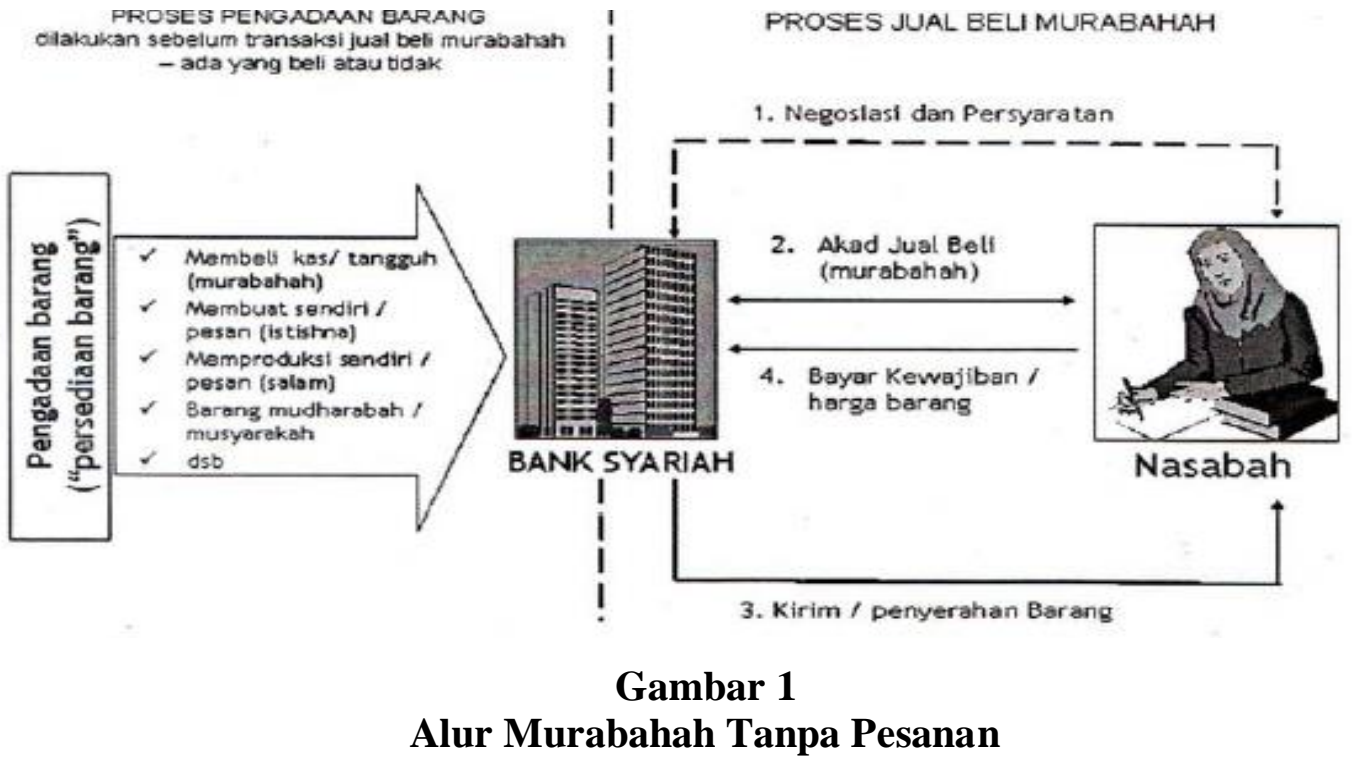

2. Murabahah berdasarkan pesanan

Murabahah berdasarkan pesanan adalah jual beli murabahah yang dilakukan setelah ada pesanan dari pemesan (nasabah) yang mengajukan pembiayaan murabahah. Dengan kata lain, bank syariah melakukan pengadaan barang dan melakukan transaksi jual beli setelah ada nasabah yang memesan untuk dibelikan barang atau aset sesuai dengan apa yang diinginkan nasabah tersebut. Alur transaksi murabahah berdasarkan pesanan dapat dilihat dari skema berikut: ${ }^{18}$

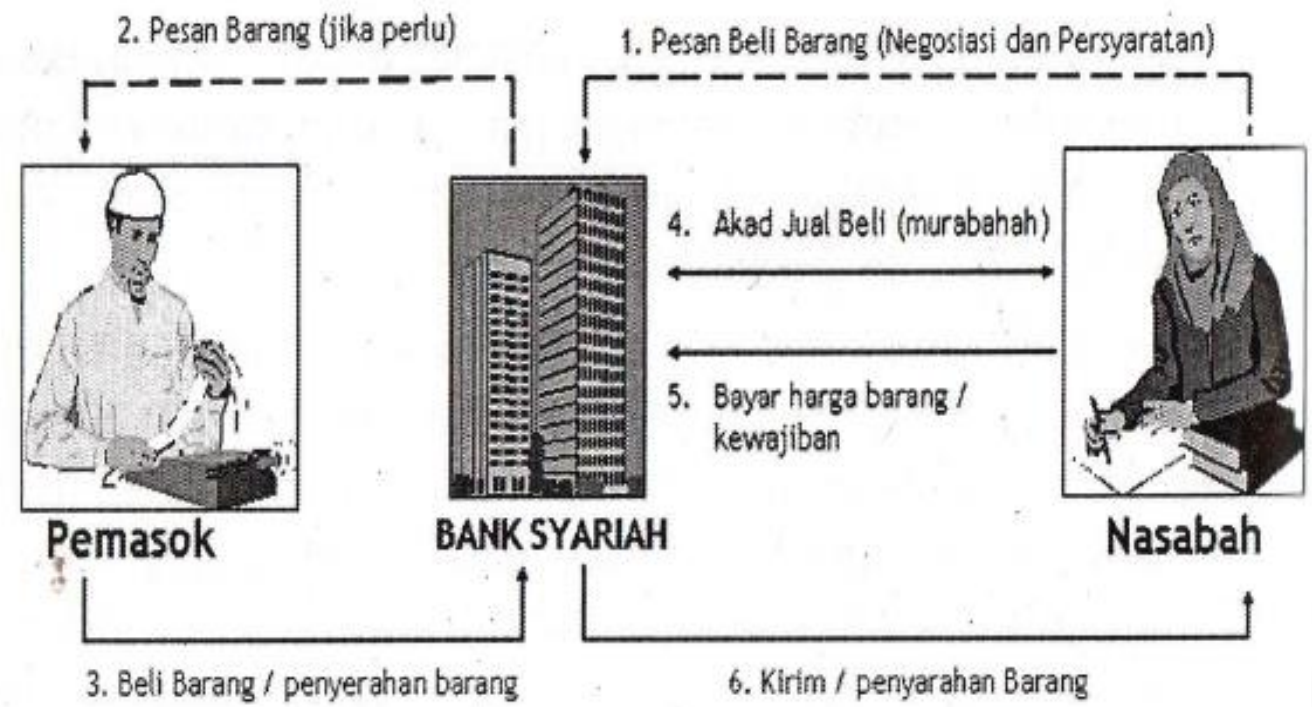




\section{Gambar 2}

\section{Alur Murabahah Berdasarkan Pesanan}

\section{Metode Penelitian}

Metode penelitian adalah langkah yang dimiliki dan dilakukan oleh peneliti dalam rangka mengumpulkan informasi atau data pada penelitian tersebut. Metode yang digunakan dalam penlitian ini yaitu berupa studi pustaka atau library research yaitu mengumpulkan atau menghimpun data-data dengan cara menggunakan bahanbahan tertulis.

\section{Pembahasan}

\section{Teknis Penerapan Murabahah di Perbankan Syariah}

Dalam teknis yang terdapat di perbankan syariah, murabahah merupakan akad jual beli yang terjadi antara pihak bank syariah dengan nasabah. Dalam hal ini, bank syariah merupakan pihak penyedia barang yang menjual kepada nasabah yang memesan dalam rangka pembelian barang tersebut. Keuntungan yang diperoleh dari pihak bank syariah dalam transaksi ini merupakan keuntungan jual beli yang telah disepakati secara bersama, dimana dalam hal ini bank selaku penjual harus memberitahu terlebih dahulu kepada pembeli (nasabah) tentang harga pokok pembelian barang dan menyertakan jumlah keuntungan yang ditambahkan pada biaya tersebut. Jual beli dengan bentuk murabahah ini terdapat dalam bentuk pesanan yang diistilahkan oleh Imam Syafi'i sebagai al-amir bi al-shira atau dapat disamakan juga dengan bay' bi tsaman ajil atau bay' muajjal (jual beli yang barangnya diserahkan segera dengan pembayaran ditangguhkan atau dilakukan secara berangsur). Oleh sebab itu, murabahah merupakan salah satu bentuk jual beli yang dihalalkan. ${ }^{19}$ Di Indonesia, aplikasi jual beli murabahah pada perbankan syariah ini didasarkan pada Keputusan Fatwa Dewan Syariah Nasional (DSN) Majelis Ulama Indonesia (MUI) yaitu Fatwa DSN Nomor 04/DSN-MUI/IV/2000 tentang ketentuan murabahah pada perbankan syariah dan Peraturan Bank Indonesia (PBI) yaitu PBI Nomor 9/19/PBI/2007 serta Surat Edaran BI Nomor 10/14/DPbs tanggal 17 Maret 2008. 
Mekanisme pembiayaan murabahah dapat digunakan untuk pengadaan barang, modal kerja, pembangunan rumah, dan lain-lain. Berikut ini beberapa contoh aplikasi pembiayaan murabahah dalam perbankan syariah. Berikut beberapa contoh aplikasi mekanisme pembiayaan murabahah dalam perbankan syariah.

Pertama, pengadaan barang transaksi ini dilakukan oleh bank syariah dengan prinsip jual beli murabahah, seperti pengadaan sepeda motor, kulkas, kebutuhan barang untuk investasi, pabrik, dan sejenisnya. Apabila seorang nasabah menginginkan untuk memiliki sebuah kulkas, ia dapat datang ke bank syariah dan mengajukan permohonan agat bank syariah membelikannya. Setelah bank syariah meneliti keadaan nasabah dan menganggap bahwa ia layak untuk mendapatkan pembiayaan untuk pengadaan kulkas, maka bank kemudian membeli kulkas dan menyerahkannya kepada pemohon (nasabah). Dalam hal ini, misalnya harga kulkas tersebut sebesar Rp 4.000.000 dan pihak bank ingin mendapatkan keuntungan sebesar Rp 800.000. Jika pembayaran angsuran selama dua tahun, maka nasabah dapat mencicil pembayarannya sebesar Rp 200.000/bulan.

Kedua, modal kerja (modal kerja barang). Penyediaan barang persediaan untuk modal kerja dapat dilakukan dengan prinsip jual beli murabahah. Akan tetapi, transaksi ini hanya berlaku sekali putus, bukan untuk satu akad dengan pembelian barang berulang-ulang. Sebenarnya, penyediaan modal kerja berupa uang tidak terlalu tepat menggunakan prinsip jual beli murabahah. Transaksi pembiayaan midal kerja dalam bentuk barang atau uang lebih tepat menggunakan prinsip mudharabah atau musyarakah karena jika pembiayaan modal kerja dalam bentuk uang menggunakan mekanisme murabahah, maka transaksi ini sama dengan consumer finance (pembiayaan konsumen) dalam bank konvensional yang mengandung unsur riba. Transaksi dalam consumer finance (pembiayaan konsumen) menggunakan pinjam meminjam uang, sedangkan dalam murabahah menggunakan transaksi jual beli.

Ketiga, renovasi rumah (pengadaan material renovasi rumah). Pengadaan material renovasi dapat menggunakan mekanisme jual beli murabahah. Barang-barang yang diperjualbelikan adalah segala bentuk barang yang dibutuhkan untuk renovasi 
rumah, seperti batu bata, genteng, cat, kayu, dan lain-lain. Transaksi dalam pembiayaan ini hanya berlaku sekali putus, tidak untuk satu akad dilakukan berulang-ulang. ${ }^{20}$

\section{Perkembangan Penggunaan Murabahah di Perbankan Syariah}

Bank-bank syariah umumnya mengadopsi murabahah untuk memberikan pembiayaan jangka pendek kepada para nasabah guna pembelian barang. Dalam praktik perbankan syariah, sebagian besar kontrak murabahah yang dilakukan adalah dengan menggunakan sistem murabahah Kepada Pemesan Pembelian (KPP). Hal ini dinamakan demikian karena pihak bank syariah semata-mata mengadakan barang atau asset untuk memenuhi kebutuhan nasabah yang memesannya. Jadi, secara umum skema dari aplikasi murabahah ini sama dengan murabahah berdasarkan pesanan.

Terdapat juga pengembangan dari aplikasi pembiayaan murabahah dalam bank syariah, yaitu dalam hal pengadaan barang. Dalam hal ini, bank syariah menggunakan media akad wakalah untuk memberikan kuasa kepada nasabah untuk membeli barang atas nama bank kepada supplier. Skema pengembangan dengan akad wakalah dari pembiayaan murabahah adalah sebagai berikut:

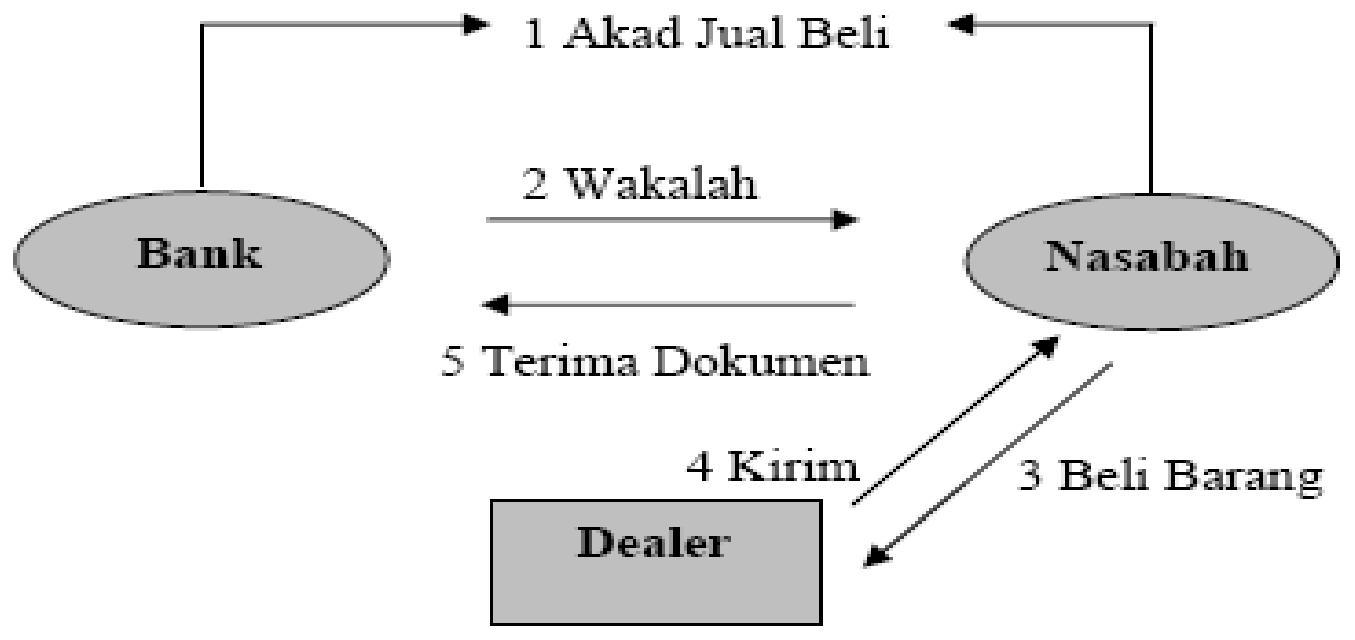

Gambar 3

\section{Skema Pengembangan Murabahah}

Dalam hal ini, apabila pihak bank mewakilkan kepada nasabah untuk membeli barang dari pihak supplier, maka kedua pihak harus menandatangani kesepakatan agency (agency contract), dimana pihak bank memberi otoritas kepada nasabah untuk menjadi agennya untuk membeli komoditas dari pihak ketiga atas nama bank. Dengan 
146 AT-TAWASSUTH: Jurnal Ekonomi Islam, Volume VI No. 1

Januari - Juni 2021: 132 - 152

kata lain, nasabah menjadi wakil bank untuk membeli barang. Kepemilikan barang hanya sebatas sebagai agen dari pihak bank. Selanjutnya, nasabah memberikan informasi kepada pihak bank bahwa ia telah membeli barang tersebut, kemudian pihak bank menawarkan barang tersebut kepada nasabah dan terbentuklah kontrak jual beli, sehingga barang pun beralih kepemilikan menjadi milik nasabah dengan segala resikonya. $^{21}$

\section{Penyimpangan Praktik Murabahah Pada Perbankan Syariah}

Praktik murabahah mengalami penyimpangan dari segi praktiknya, sehingga praktik tersebut menjadi bathil bahkan berpotensi menjadi dzalim. Namun, penyimpangan ini seolah dibiarkan dan terus berlangsung hingga saat ini.

\section{Pelanggaran syarat milkiyah}

Syarat kepemilikan merupakan hal yang mutlak dalam jual beli. Rasulullah saw. melarang menjual barang yang belum dimiliki olehnya. Dalam sebuah hadits yang diriwayatkan Imam Ahmad dari Hakim bin Hazam, Rasulullah saw. bersabda, "Janganlah menjual barang yang belum dimiliki olehnya". Syarat kepemilikan ini sering dilanggar oleh perbankan dalam menjalankan akad murabahah yang diwakilkan kepada nasabah, sehingga akad tersebut menjadi bathil. Dalam ushul fiqh dikatakan sesuatu dikatakan sah jika rukun dan syarat terpenuhi, jika tidak terpenuhi maka sesuatu menjadi bathil. Dalam praktiknya, perbankan syariah menyelesaikan akad murabahah sementara ia belum memiliki barang yang dijualnya, setelah akad murabahah terselesaikan barulah perbankan menyelipkan akad wakalah yang mewakilkan nasabah untuk membeli barang yang sesuai dengan pesanan. Seharusnya agar praktik ini sesuai dengan syariah, perbankan harus menyelesaikan akad wakalah terlebih dahulu agar syarat kepemilikan terpenuhi, barulah kemudian dilangsungkan akad murabahah. Hal ini juga sesuai dengan Fatwa DSN-MUI Nomor 04/DSN-MUI/IV/2000 tentang murabahah pada ketentuan murabahah dalam bank syariah poin sembilan dikatakan bahwa "Jika bank hendak mewakilkan kepada nasabah untuk membeli barang dari pihak ketiga, akad jual beli murabahah harus dilakukan setelah barang secara prinsip menjadi milik bank. 


\section{Pelanggaran syarat ra'sul mal ma'lum}

Pelanggaran jenis ini juga terjadi karena pada struktur murabahah dengan mewakilkan nasabah untuk membeli barang yang dipesan, sebagaimana disebutkan sebelumnya, syarat ra'sul mal (modal) dan ribh (keuntungan) haruslah diketahui merupakan syarat khusus pada jual beli murabahah. Pelanggaran ini biasanya terjadi ketika nasabah ingin melakukan pembiayaan murabahah, kemudian pihak bank menawarkan beberapa besaran platform pembiayaan tersebut beserta margin keuntungan yang diambil oleh bank. Bank tidak mengambil keuntungan berdasarkan besaran dari ra'sul mal, namun dari besaran uang yang dikeluarkan oleh bank. Bahkan, dalam beberapa kasus pihak bank syariah tidak peduli dengan besaran harga dari ra'sul mal. Pelanggaran pada jenis inilah yang kemudian disebut dengan pintu lain menuju riba. Dalam jual beli harus ada komoditas yang dibeli. Jika tidak, maka tidak ada bedanya dengan bunga pada perbankan konvensional.

3. Penempatan akad yang tidak tepat

Murabahah merupakan salah satu dari bentuk jual beli, sehingga akad ini hanya berlaku pada praktik jual beli saja. Namun, terjadi penempatan akad murabahah pada transaksi yang salah, misalnya pembiayaan untuk renovasi rumah. Hal ini tidak bisa dilakukan dengan akad murabahah karena tidak terpenuhinya syarat malikiyah (kepemilikan) dan ra'sul mal (modal) yang diketahui. Seharusnya, akad yang tepat pada jenis tersebut adalah akad istisna' paralel. Dalam akad ini, bisa saja pembeli mengizinkan pembuat menggunakan subkontraktor untuk melaksanakan kontrak tersebut. Dengan demikian, pembuat kontrak istishna' kedua untuk memenuhi kewajibannya pada kontrak pertama. ${ }^{22}$

Pada dasarnya, produk-produk bank syariah merupakan ijtihad. Jadi, wajar saja dalam hal penerapannya di bank syariah terdapat beberapa khilafiah (perbedaan pendapat). Tetapi, perbedaan pendapat itu bukan berarti dapat melakukan pelanggaran dengan alasan agar transaksi lebih mudah dilakukan oleh bank syariah. Tentu saja hal ini sudah menyalahi aturan yang ada karena pada prinsipnya bank syariah dalam menerapkan produk-produk atau akad-akad terutama untuk transaksi pembiayaan harus menggunakan prinsip kehati-hatian. Di Indonesia, kita sudah memiliki rujukan 
yang mana rujukan ini dijadikan pedoman untuk penerapan produk-produk di perbankan syariah, seperti fatwa DSN-MUI, PBI, dan lain-lain. Hal ini perlu diterapkan di berbagai bank syariah di Indonesia agar segala hal baik terkai mengenai penerapan produk-produk, akad-akad, ataupun hal lainnya sesuai dengan standard yang telah ditetapkan. Selain itu, bank syariah merupakan lembaga keuangan yang lebih luas dibandingkan dengan bank konvensional, sehingga bank syariah memiliki banyak pilihan akad untuk menerapkan atau menentukan suatu transaksi pembiayaan.

\section{Isu Terkini Mengenai Murabahah Pada Perbankan Syariah}

Bila dilihat secara sederhana, bunga bank dan murabahah dengan sistem tunda tidak memiliki perbedaan, keduanya kelihatan sama-sama menggunakan nilai waktu uang. Perbedaan diantara keduanya hanya terletak pada perbedaan akadnya saja, sistem bunga menggunakan akad hutang piutang, sementara murabahah menggunakan akad jual beli. Hal ini sering diungkapkan terutama oleh tokoh-tokoh yang cenderung membela sistem bunga. Mereke berusaha untuk mencari kelemahan dan kekurangan dari sistem pembiayaan murabahah. Sebenarnya, terdapat dua hal yang perlu dijelaskan untuk menjawab semua tudingan mereka terkait mengenai pembiayaan murabahah, yakni: Pertama, terkait dengan akad dan implikasi akad. Kedua, terkait dengan time value of money.

1. Perbedaan akad murabahah dan hutang piutang

Secara bahasa bai' berarti pertukaran sesuatu dengan sesuatu, sedangkan dari segi istilah bai' berarti pertukaran harta dengan harta dengan cara yang khusus atau pertukaran sesuatu yang diinginkan dengan yang sepadan dengan cara yang khusus.

Pertukaran tersebut menyebabkan berpindahnya hak milik. Sementara, hutang berarti memberikan harta kemudian untuk diminta kembali. Dari defenisi akad tersebut dapat dipahami bahwa jual beli terjadi pertukaran dan pemindahan hak milik antara dua pihak yang berakad, sedangkan hutang tidak terjadi pertukaran kepemilikan. Dalam praktik perbankan syariah, akad murabahah merupakan salah satu bentuk jual beli, sebagaimana dipahami sebelumnya bahwa akad jual beli merupakan akad pertukaran yang menyebabkan berpindahnya hak milik. Hal ini juga memberikan implikasi yang sama pada akad murabahah, ketika nasabah 
sebagai pembeli mengalami penunggakan dalam pembayaran atau bahkan tidak mampu membayar, maka dalam hal ini pihak bank sebagai penjual tidak berhak untuk menyita barang yang sudah dibeli tersebut karena telah terjadi perpindahan kepemilikan. Oleh karena itu, untuk penyelesaiannya mungkin dapat dilakukan penjadwalan ulang atau pihak nasabah dapat menjual barang tersebut secara normal, kemudian hasil penjualan tersebut dibayarkan kepada pihak bank untuk sisa dari penunggakan tersebut. Sementara dalam hutang, ketika terjadi penunggakan pembayaran, maka pihak bank berhak untuk menyitanya, sebab tidak ada perpindahan kepemilikan karena secara hukum barang tersebut masih milik bank selama nasabah belum melunasinya. Biasanya, barang tersebut akan dilelang oleh pihak bank untuk menutup sisa hutang nasabah. Tentu saja, pelelangan tersebut tidak memberikan harga yang normal, sehingga hal ini menyebabkan ketidakadilan bagi nasabah.

\section{Murabahah dan time value of money}

Pernyataan selanjutnya yang sering diungkapkan yaitu bahwa murabahah dengan sistem tunda, dimana harga tunda lebih besar dari harga normal tak ubahnya dengan time value of money. Persyaratan pembayaran dalam murabahah klasik tidak selalu melibatkan sistem tunda, dapat berbasis tunai ataupun tunda (muajjal). Kebanyakan fuqaha dari pengikut Hanafi, Syafi'i, dan Hambali meyakini bahwa penjual dapat memberikan dua harga, yang satu untuk transaksi tunai dan yang lainnya untuk transaksi kredit (cicil), tetapi salah satu dari kedua harga tersebut harus ditetapkan pada saat akad. Walaupun, Imam Malik melarangnya, namun sebagian pengikut mazhab Maliki memiliki pandangan berbeda dan membolehkannya. Imam Turmidzi menjelaskan bahwa jika penjual mengatakan bahwa ia menjual pakaian seharga Rp 100.000 secara tunai dan seharga Rp 200.000 secara mu'ajjal serta pembeli menerima salah satu dari kedua harga tersebut dan kedua belah pihak tersebut berpisah setelah menyelesaikan salah satu harga, maka penjualan tersebut sah selama yang diperjualbelikan itu adalah komoditas. Hal ini sangat berbeda dengan konsep time value of money yang dipengaruhi oleh teori kapitalis modern. Dalam teori kapitalis modern, uang dan komoditas diperlakukan sama, sehingga uang bisa diperjualbelikan dan disewakan. Sementara dalam prinsip muamalah Islam, uang 
dan komoditas memiliki karakteristik yang berbeda. Uang hanya sebagai alat ukur yang tidak memiliki nilai intrinsik, sedangkan komoditas memiliki nilai instrinsik yang bisa diperdagangkan. ${ }^{23}$

\section{Kesimpulan}

Dalam teknis yang terdapat di perbankan syariah, murabahah merupakan akad jual beli yang terjadi antara pihak bank syariah dengan nasabah. Dalam hal ini, bank syariah merupakan pihak penyedia barang yang menjual kepada nasabah yang memesan dalam rangka pembelian barang tersebut. Keuntungan yang diperoleh dari pihak bank syariah dalam transaksi ini merupakan keuntungan jual beli yang telah disepakati secara bersama, dimana dalam hal ini bank selaku penjual harus memberitahu terlebih dahulu kepada pembeli (nasabah) tentang harga pokok pembelian barang dan menyertakan jumlah keuntungan yang ditambahkan pada biaya tersebut.

Pengembangan dari aplikasi pembiayaan murabahah dalam bank syariah, yaitu dalam hal pengadaan barang. Dalam hal ini, bank syariah menggunakan media akad wakalah untuk memberikan kuasa kepada nasabah untuk membeli barang atas nama bank kepada supplier. Dengan kata lain, nasabah menjadi wakil bank untuk membeli barang. Kepemilikan barang hanya sebatas sebagai agen dari pihak bank. Selanjutnya, nasabah memberikan informasi kepada pihak bank bahwa ia telah membeli barang tersebut, kemudian pihak bank menawarkan barang tersebut kepada nasabah dan terbentuklah kontrak jual beli, sehingga barang pun beralih kepemilikan menjadi milik nasabah dengan segala resikonya.

Penyimpangan-penyimpangan yang terjadi dalam praktik murabahah pada perbankan syariah, antara lain: pelanggaran syarat milkiyah, pelanggaran syarat $r a$ 'sul mal ma'lum, dan penempatan akad yang tidak tepat.

\section{Endnote}

${ }^{1}$ Herni Ali dan Miftahurrohman, "Determinan yang Mempengaruhi Pembiayaan Murabahah pada Perbankan Syariah di Indonesia ", Jurnal Bisnis dan ManajemenVolume 6 Nomor 1, April 2016, hlm. 32. 
2 Bagya Agung Prabowo, “Konsep Akad Murabahah pada Perbankan Syariah (Analisa Kritis Terhadap Aplikasi Konsep Akad Murabahah di Indonesia dan Malaysia)", Jurnal HukumVolume 16 Nomor 1, Januari 2009, hlm. 106.

3 Wardah Yuspin, "Penerapan Prinsip Syariah dalam Pelaksanaan Akad Murabahah", Jurnal Ilmu HukumVolume 10 Nomor 1, Maret 2007, hlm. 56.

${ }^{4}$ Lukmanul Hakim dan Amelia Anwar, "Pembiayaan Murabahah pada Perbankan Syariah dalam Perspektif Hukum di Indonesia", Jurnal Ekonomi Syariah dan Filantropi IslamVolume 1 Nomor 2, Desember 2017, hlm. 212.

5 Herni Ali dan Miftahurrohman, Op. Cit., hlm. 32.

6 Bagya Agung Prabowo, Op. Cit., hlm. 108.

7 Lukmannul Hakim dan Amelia Anwar, Op. Cit., hlm. 214.

8 Sofyan Sulaiman, "Penyimpangan Akad Murabahah di Perbankan Syariah dan Beberapa Isu Mengenai Murabahah”, Jurnal MadaniaVolume 7 Nomor 1, 2017, hlm. 190.

${ }^{9}$ Ibid., hlm. 195.

${ }^{10}$ Sofyan Sulaiman, “Evaluasi Praktik Murabahah pada Perbankan Syariah di Indonesia Sebuah Analisis Fiqh", Jurnal SyariahVolume 2 Nomor 2, Oktober 2014, hlm. 26.

${ }^{11}$ Ibid., hlm. 27.

12 Sofyan Sulaiman, Op. Cit., hlm. 196.

${ }^{13}$ Muhammad Nizar, "Implementasi Pembiayaan Murabahah dalam Meningkatkan Profitabilitas", Jurnal An-NisbahVolume 2 Nomor 1, Oktober 2015, hlm. 239-240.

${ }^{14}$ Ibid., hlm. 240-241.

${ }^{15}$ Ikatan Bankir Indonesia, Memahami Bisnis Bank Syariah (Jakarta: PT Gramedia Pustaka Utama, 2014), hlm. 22-27.

16 FR Famuktiathur, "BAB II Tinjauan Umum Tentang Murabahah", eprints.walisongo.ac.id(diunduh pada tanggal 21 Maret 2020, pukul 21;47 WIB).

${ }^{17}$ Loc. Cit.

18 Loc. Cit.

${ }^{19}$ Yenti Afrida, “Analisis Pembiayaan Murabahah di Perbankan Syariah”, Jurnal Ekonomi dan Bisnis IslamVolume 1 Nomor 2, Juli-Desember 2016, hlm. 158.

${ }^{20}$ Ah. Azharuddin Lathif, "Konsep dan Aplikasi Akad Murabahah pada Perbankan Syariah di Indonesia", Jurnal AhkamVolume 12 Nomor 2, Juli 2012, hlm. 73-76.

${ }^{21}$ FR Famuktiathur, Op. Cit.

22 Sofyan Sulaiman, Op. Cit., hlm. 29-31.

${ }^{23}$ Ibid., hlm. 35-37.

\section{Daftar Pustaka}

Afrida, Yenti. 2016. Analisis Pembiayaan Murabahah di Perbankan Syariah. Jurnal Ekonomi dan Bisnis Islam, Vol. 1, No. 2, Juli-Desember 2016.

Ali, Herni dan Miftahurrohman. 2016. Determinan yang Mempengaruhi Pembiayaan Murabahah pada Perbankan Syariah di Indonesia. Jurnal Bisnis dan Manajemen, Vol. 6, No. 1, April 2016.

Famuktiathur, FR. BAB II Tinjauan Umum Tentang Murabahah, eprints.walisongo.ac.id, (21 Maret 2020 pukul 21.47 WIB).

Hakim, Lukmanul dan Anwar, Amelia. 2017. Pembiayaan Murabahah pada Perbankan Syariah dalam Perspektif Hukum di Indonesia. Jurnal Ekonomi Syariah dan Filantropi Islam, Vol. 1, No. 2, Desember 2017. 
152 AT-TAWASSUTH: Jurnal Ekonomi Islam, Volume VI No. 1

Januari - Juni 2021: 132 - 152

Ikatan Bankir Indonesia. 2014. Memahami Bisnis Bank Syariah. Jakarta: PT Gramedia Pustaka Utama.

Lathif, Ah. Azharuddin. 2012. Konsep dan Aplikasi Akad Murabahah pada Perbankan Syariah di Indonesia. Jurnal Ahkam, Vol. 12, No. 2, Juli 2012.

Nizar, Muhammad. 2015. Implementasi Pembiayaan Murabahah dalam Meningkatkan Profitabilitas. Jurnal An-Nisbah, Vol. 2, No. 1, Oktober 2015.

Prabowo, Bagya Agung. 2009. Konsep Akad Murabahah pada Perbankan Syariah (Analisa Kritis Terhadap Aplikasi Konsep Akad Murabahah di Indonesia dan Malaysia). Jurnal Hukum, Vol. 16, No. 1, Januari 2009.

Sulaiman, Sofyan. 2014. Evaluasi Praktik Murabahah pada Perbankan Syariah di Indonesia Sebuah Analisis Fiqh. Jurnal Syariah, Vol. 2, No. 2, Oktober 2014.

Sulaiman, Sofyan. 2017. Penyimpangan Akad Murabahah di Perbankan Syariah dan Beberapa Isu Mengenai Murabahah. Jurnal Madania, Vol. 7, No. 1, 2017.

Yuspin, Wardah. 2007. Penerapan Prinsip Syariah dalam Pelaksanaan Akad Murabahah. Jurnal Ilmu Hukum, Vol. 10, No. 1, Maret 2007. 